\title{
DEFENCE INDUSTRY IN THE EUROPEAN UNION - CHALLENGES AND OPPORTUNITIES IN TIMES OF ECONOMIC CRISIS
}

Europe is the birthplace of modern industry. The Industrial Revolution of the late $18^{\text {th }}$ century secured this continent's position as the prime global centre of economic, political and military power for the next two hundred years. In the second half of the $20^{\text {th }}$ century and in first decades of the next one, Europe's place in the world balance of economic power gradually declined. Competition from new industrial powerhouses of North America and Asia, together with globalisation-driven offshoring and deindustrialisation proved to be formidable challenges for the continent's manufacturing sector. Although, at the beginning of the Industrial Revolution, this new sector's activity was civilian in nature, the military applications of new technologies were quickly appreciated. The defence (or arms) industry quickly developed into one of the leading manufacturing sectors in terms of scale, profits and technological innovation. It paved the way for the massive total warfare as witnessed in the first half of the $20^{\text {th }}$ century. In this field Europe was both a precursor and leader for about 200 years. Forty years of cold war struggle allowed for the maintenance of extensive military-industrial potential in Western as well as Eastern Europe. Even after the collapse of the bipolar international order EU-based companies remained among the top players in the global arms market.

The current period of financial and economic crisis (initiated by the collapse of Lehman brothers at $15^{\text {th }}$ September 2008) could prove to be a turning point for the future of European defence industry. The fiscal retrenchment in most EU states and turbulence in the global markets confront this sector with some hard questions. The purpose of this article is to analyse the current situation faced by the European defence sector and sketch possible scenarios of its future developments. For this purpose, the model of SWOT analysis has been applied. It allowed to take into consideration both internal (strengths and weaknesses) as well as external (threats and opportunities) factors influencing the current state of the industry. In field of arms manufacturing political, economic and military issues intersect. That is why the future of defence sector in the EU carries important implications for the community's security, as well as economic development.

\section{EUROPEAN DEFENCE INDUSTRY - BRIEF OVERVIEW}

When considering the future prospects for the European defence sector, it is useful to first quickly review its size, market position and main players. Useful data can be found in publications of the AeroSpace and Defence Industries Association of Europe 
(ASD). This organization has member association in 20 states (17 EU member states, Norway, Switzerland and Turkey). ${ }^{1}$ It compiles some basic statistics useful for the evaluation of the European defence industry's size and performance. However, two caveats are in place. First, the data come only from the 20 states whose companies participate in the works of the association. Second, the organization deals not only with the defence sector, but also with the broader aerospace industry which operates in both civilian and military markets. According to ASD data, in year 2010 the turnover of the aerospace and defence industry was $€ 162.9 \mathrm{bn}$ (with a $58: 42 \%$ share in favor of business's civil side). Companies from these sectors directly employed 704,200 people $(500,000$ of them in the aerospace sector). Data for Research\&Development (R\&D) expenditure cover only the aerospace sector. This effort amounted to $€ 13 \mathrm{bn}$. Industry's operating profit margin was $6,8 \% .{ }^{2}$ Those data show that the European defence industry is generally in good commercial condition. It is also noteworthy that the aerospace sector seems to be the main driver for growth and development.

European producer's position on the global defence market is reflected in the arms transfers data compiled by the Stockholm International Peace Research Institute (SIPRI). In the 2001-2011 period, six out of ten top global exporters were EU member states. They were: Germany (position no. 3), France (no. 4), UK (no. 5), Netherlands (no. 7), Italy (no. 9), and Sweden (no. 10). During that period, these six states exported arms and military equipment worth ca. $\$ 70 \mathrm{bl}^{3}{ }^{3}$ It is also noteworthy that the Top 100 defence companies list published by the "Defense News" magazine, is dominated by US and EU companies. Among ten biggest defence companies in year 2010 seven were American and the remaining three were West European: BAE Systems (UK, ${ }^{4}$ position no. 2), EADS (Netherlands, no. 7) and Finmeccanica (Italy, no. 8). ${ }^{5}$

\section{FUNCTIONS OF THE DEFENCE INDUSTRY}

In order to properly understand and evaluate the significance of the defence sector for the EU and its member states, it is important to first analyse functions which are performed by this industry in general (around the world). In author's opinion, there are four main functional areas which explain the industry's utility for the state, economy and society:

- Military - naturally, the most basic task of the defence industry is to support the state's defence posture in peacetime and military effort in wartime. Modern armed

1 ASD Facts \& Figures - 2010, http://www.asdeurope.org/site/fileadmin/images/publications_thumbs/FF2010.pdf (8.06.2012), p. 2.

${ }^{2}$ Ibidem, p. 4.

3 Stockholm International Peace Research Institute, Arms Transfers Database, http://armstrade.sipri.org/armstrade/html/export_toplist.php (8.06.2012).

${ }^{4}$ It is important to remember, that although BAE Systems is a UK registered company, large part of its turnover comes from the US subsidiary. BAE Systems Inc., http://www.baesystems.com/ our-company-rus/bae-systems-inc-rus (8.06.2012).

5 Defense News Top 100 for 2010, http://special.defensenews.com/top-100/charts/rank 2010.php? $=$ FEA\&s $=$ T1C $(8.06 .2012)$. 
forces require vast quantities of sophisticated weapon systems and other military equipment. Since the beginning of the Industrial Revolution (or, more precisely, the widespread application of its achievements for military purposes) warfare has become ever more technology-intensive. During the great armed conflicts of the $20^{\text {th }}$ century technology's role as one of the main factors shaping the outcome of military struggle was clearly established. Developments of the late $20^{\text {th }}$ and early $21^{\text {st }}$ century (the drive towards another Revolution in Military Affairs and Network-Centred-Warfare) point to ever greater role of technology for the successful conduct of military operations. ${ }^{6}$ Defence industry's military function is derived from three basic tasks. First, at the most basic level, this sector is supposed to supply the military with arms and military equipment at the qualitative and quantitative level deemed necessary for the successful execution of military operations. Second, defence industry provides the technological base for the maintenance and development of military potential. Large part of R\&D work conducted for military purposes is done by the industry. Finally, what is sometimes overlooked, defence contractors play crucial role in maintenance of the weapon systems during their entire life-cycle. They provide training, technical services, repairs, updates and many other support functions. In recent decades growing trend towards cost reduction has led to outsourcing of some crucial military capabilities (like, for example, training or aerial refuelling) to the private sector. ${ }^{7}$

- Political - much has been said and written about the military-industrial complex and its political influence. ${ }^{8}$ For the purpose of this paper those deliberations had been put aside. Instead, the utility of the defence industry for state's foreign and security policy will be analysed. From the very beginning the arms trade was intertwined with international politics. Leading powers were able to influence their allies and shape the dynamic of armed conflicts through facilitation or denial of arms transfers. As states seek to obtain modern weaponry, which they view as essential for their military security, those who posses such technologies can gain significant political influence. Nevertheless, it is important to remember that circumstances in the global defence market have changed significantly during the last several decades. In the past, arms market was practically a "seller's market". Not many states possessed the capability to manufacture sophisticated weapons. Those who did utilized it primarily for the

${ }^{6}$ See for example: Network Centric Warfare: Background and Oversight Issues for Congress, CRS Report for Congress, 18.03.2005, http://www.au.af.mil/au/awc/awcgate/crs/rl32411.pdf (22.06.2012); D. S. Alberts, J. J. Garstka, F. P. Stein, Network Centric Warfare: Developing and Leveraging Information Superiority, CCRP publication series, 2000, http://www.au.af.mil/au/awc/awcgate/ccrp/ncw.pdf (22.06.2012).

7 Good examples of this trend can be found in the UK in the form of UK Military Flying Training System - Ascent's Long-Term UKMFTS Contract for Military Flight Training, "Defense Industrial Daily", 15.06.2011, http://www.defenseindustrydaily.com/ascent-rises-to-preferred-position-in-gbp-6b-contract-for-uk-military-flight-training-02839/\#british-aicraft-trainers (23.06.2012) or the AirTanker consortium - AirTanker, About us, http://www.airtanker.co.uk/about-us (23.06.2012).

${ }^{8}$ See for example: B. Brunton, An historical perspective on the future of the military-industrial complex, "Social Science Journal" 1991, Vol. 28, No. 1; E. Gholz, The Curtiss-Wright Corporation and Cold War-Era Defense Procurement A Challenge to Military-Industrial Complex Theory, "Journal of Cold War Studies" 2000, Vol. 2, No. 1. 
domestic purposes. Leading producers could pick and choose their buyers. Right now, in the post-cold war world, leading defence contractors face declining domestic markets and rising international competition. That is why currently we can talk about the "buyer's market" in defence goods. The biggest customers (like for example India) can now pick and choose among offers from leading global suppliers. Defence industry's political function is also derived from the "security of supply" it provides. When weapons and military equipment are imported, the supplier exercises a level of control over the operational capability of buyer's military. Finally, the capability for development and production of sophisticated weapon systems grants the state a considerable international prestige.

- Economic - as shown by the ASD data cited above, defence industry is a profitable commercial enterprise. In the course of the $20^{\text {th }}$ century expansion of military materiel production was used as a stimulus for the national economy (for example, the intensive build-up during the World War II provided much needed expansion for the US economy). Defence sector's advantage in comparison with other fields of manufacturing is its lesser dependence on business cycles. Although the arms market is not completely immune from influences of recession or crisis (as visible in recent years), their effects are less acute. In general, it can be stated that demand for military equipment is less flexible than in the case of other commercial goods. What is important, defence sector can definitely be counted as one of the so called "high-tech industries". It has long been one of the prime innovators and many technologies developed for the benefit of the military have "spilled-over" to the civilian world.

- Welfare - considering the socio-economic developments of the last two decades in Europe, it can be argued that the defence industry has an important welfare role to fulfil. Globalisation has lead to far-reaching changes in the European industrial landscape. The traditional heavy industry (like for example steel making or shipbuilding) shifted its main manufacturing operations into lower-cost developing economies (chief among them China). As a consequence, the continent faced so called "industrial decline". The consequences of this process are not only purely economic. The social and welfare impact has also been considerable. The loss of traditional manufacturing jobs unsettled the established socio-economic system. Traditional industrial areas faced rising unemployment and other socioeconomic ills associated with it. In this context, it can be argued that the defence industry is one of the last heavy industry sectors remaining in Europe. Moreover, its relocation is highly improbable due to its sensitive military and political functions described above. Thus, defence production creates opportunities for large scale employment for the traditional industrial workforce.

\section{INTERNAL STRENGTHS}

The EU-based defence industry has several important internal strengths, which foster its ability to effectively compete in both domestic and international markets. Chief among them are: strong market position, rich and diverse range of products, expertise in some of the most promising sectors of the market, experience in multinational industrial cooperation and synergy with the civilian operations. 
European defence companies are principal suppliers dominating the EU markets for arms and military equipment. According to data provided by the ASD (for year 2010), its member companies provided $3 / 4$ of the total defence investment undertaken by 20 states covered. ${ }^{9}$ This amounted to ca. $€ 45 \mathrm{bn}$ from a total sum of abut $€ 60 \mathrm{bn}$ invested. In the same year, exports by ASD-affiliated military aerospace/defence companies amounted to $€ 23 \mathrm{bn}$ in intra-EU transfers and additional $€ 25 \mathrm{bn}$ of sales to non-EU customers ( $20 \%$ of it to the USA). ${ }^{10}$ In "A Strategy for a stronger and more competitive European defence industry" prepared by the European Commission in year 2007 information can be found, that European defence industry accounts for $30 \%$ of world production. ${ }^{11}$ In the aforementioned list of top 100 defence companies compiled by the "Defence News" magazine, entities from the EU comprise almost a quarter of the entire pool (24 companies). ${ }^{12}$

Market attractiveness of European industry's offer is derived from (among other factors) its diversity and flexibility. Currently, EU-based suppliers are able to manufacture most of the internationally tradable categories of arms and military equipment. What is important, they can offer products from different segments suited for needs and financial abilities of different customers. Europe can develop and produce a wide range of military systems. On one side of the spectrum there are sophisticated weapon systems, like for example modern multirole combat aircraft (three types are being manufactured in the EU- Dasault Rafale, Eurofighter Typhoon and Saab JAS-39 Gripen), heavy Armoured Combat Vehicles (for example Main Battle Tanks - Leopard 2, Leclerc, Challenger 2, Ariette, or Puma Infantry Combat Vehicle) or nuclear submarines (build in France and UK, naturally, for domestic use only) and fleet carriers (again France and UK posses these capabilities). At the lower end of operational capabilities (and cost) there are, for example, light transport aircraft (like those offered by EADS $C A S A$ or Alenia), light armoured vehicles (wide range of producers) or Offshore Patrol Vessels/smaller surface combatants (the Gowind family, offered by the French DCNS, can provide a useful example ${ }^{13}$ ). This flexibility can offer advantages in competition, especially with the US companies. As they develop their products mainly for their own armed forces, they are naturally suited for its structure, tasks and doctrine. While the USA is the sole superpower, its defence contractors often provide systems with capabilities (and most importantly costs) far exceeding the needs and abilities of great majority of other states.

European defence sector includes champions of some important market segments which show good prospects for future growth. One of the most prestigious and profitable segments of the arms market concerns the multirole combat aircraft. As mentioned earlier, currently three EU-based companies produce such machines: French Dassault

9 That means state of origin for companies associated in the ASD - 17 EU members, Norway Switzerland and Turkey.

${ }^{10}$ ASD Facts \& Figures, op. cit., pp. 8-9.

${ }_{11}$ A Strategy for a stronger and more competitive European defence industry, http://eur-lex.europa.eu/LexUriServ/LexUriServ.do?uri=COM:2007:0764:FIN:en:PDF (11.06.2012), p. 2.

12 Defense News Top 100 for 2010, op. cit.

13 Gowind Corvettes, France, "naval-technology.com", http://www.naval-technology.com/projects/gowind_corvettes/ (23.06.2012). 
Aviation (Rafale), Eurofighter Gmbh (a 4-nation consortium - Germany/Italy/Spain/UK, Eurofighter Typhoon) and Swedish Saab (JAS-39 Gripen). In recent years, transport and tanker aircraft received growing attention from buyers around the globe. Airbus Military, the defence arm of leading aircraft manufacturer, is well positioned to satisfy this demand with a range of products (starting with light $C A S A C N-235$ and $C-295$ aircraft, newly developed $A 400 M$ and Multi Role Transport Tanker series adopted from airliners). Recent armed conflicts (primarily in Afghanistan and Iraq) reaffirmed great usefulness of helicopters for modern military operations. European companies Agusta Westland and Eurocopter are among the leading global suppliers of such aircraft. The MBDA group is one of the main global players in the field of missile technology. It can offer almost all categories of air, land, surface and subsurface launched missiles and more widely precision guided munitions. Recently, it entered the elite market for missile defence systems. ${ }^{14}$

In the context of RMA and NCW concepts development it is hardly surprising that defence electronics generate substantial profits. European companies with significant expertise in this regard are (among others) Thales and Selex Sistemi Integrati (currently part of Finmeccanica). Recent combat experience has driven demand for armoured vehicles of different types. Such European companies like: Krauss-Maffei Wegman, Rheinmetall Defence, Iveco Defence Vehicles, Patria, Nexter, BAE Land\&Armaments have earned a high reputation in this segment of the market. The small arms market is often overlooked as the per-item price for such weapons is relatively low. However, it must be remembered that every military/paramilitary/police force needs such arms in large quantities. There are many respected small arms producers in Europe, but two firms stand out. German Heckler\&Koch and Belgian FN Herstall have a long history of significant presence in the global market. They offer a wide range of small arms and both have secured many prestigious contracts (among them for the US military, especially for the US Special Operations Command). Finally, in the naval sector such large contractors like the French DCNS or German ThyssenKrupp Marine Systems have a very strong position as suppliers of both surface and subsurface combatants. In fact the international market for conventionally powered submarines is practically dominated by EU and Russian companies.

Trends in the global defence market point to a growing demand for rather novel competency which is expertise in management and successful completion of multinational co-development programmes. In the past, military equipment was typically developed in form of national programmes or procured from foreign contactors as a finished product. In the post-cold war period, joint development through international industrial programmes proliferated. There are two main factors driving this process. First, modern weapon systems became so technologically complicated and costly that even the richest states face significant difficulties in successfully developing them on their own. Even the USA pursues multinational programmes (chief among them the Joint Strike Fighter). West European states, whose defence expenditure and technological-industrial base had been historically smaller than American, arrived at those con-

14 N. Bühl, MBDA - A Test Case for the European Defence Sector?, "Military Technology" 2011, no. 5 , pp. $14-16$. 
clusions much earlier. Second factor driving this "multilateralisation" of weapon system's development are growing demands of export customers. Leading importers (like for example India or the Gulf region states) are no longer satisfied with purchases of complete defence products. They strive to develop their own industry in order to achieve a degree of self-sufficiency. Those states are also eager to secure promotion for their industries in the global division of labour into high-technology echelon. That is why they demand co-development as part of their procurement strategies. Mayor global players, facing difficult and highly-competitive market are prepared to satisfy those demands.

As already mentioned, European companies have extensive experience in multinational endeavours. In the span of last 50 years, West European states have pursued numerous co-development and co-production programmes. Currently there are several such endeavours under way across the continent, like for example: Eurofighter, $\mathrm{NH} 90$ helicopter, A400M transport aircraft, FSAF and PAAMS air defence systems, Tiger attack helicopter or Boxer armoured vehicle. ${ }^{15}$ Although those programmes are not free of challenges, stemming primarily from differences in national requirements and arguments about the work share among participants, it can be argued that European defence suppliers have the greatest expertise in this field from all global market participants. Several examples of how those skills were put to good use in order to secure export contracts can be named. In order to secure order for its submarines from Brazil, French DCNS provided a package which included not only the ships themselves, but also assistance in development of shipyard, naval base and nuclear propulsion programme ${ }^{16}$ Interesting case is the joint offer of $M B D A$ and Polish Bumar group of the "Shield of Poland" system of systems for air defence. The European partner agreed to participate in development and further exports of system combining its missiles with Polish electronics, command and control systems and various other sub-systems. ${ }^{17}$

Another important factor working to the strength of the European defence sector is its growing integration and synergy with the civilian sector. As already mentioned, ASD statistics show that in year 2010 civil business activity provided $58 \%$ of the aerospace and defence industry's turnover. ${ }^{18}$ The same source recognizes the civil aeronautics as the most important sector of the ASD industry in terms of turnover. In the aeronautics field itself, the civilian side of business activity clearly dominates its military counterpart in financial terms (constituting 60\% of European aeronautics industry's turnover). ${ }^{19}$ Close links between civilian and military production are nothing new. Many technologies used for arms and military equipment development and production are dual-use in nature. That is way many companies contribute to the wider

15 P. Donaldson, Major European Defence Programmes, "Military Technology" 2011, no. 9, pp. 63-70.

16 Brazil \& France in Deal for SSKs, SSN, "Defense Industry Daily", 23.04.2012, http://www.defenseindustrydaily.com/Brazil-France-in-Deal-for-SSKs-SSN-05217/ (21.06.2012).

17 A. Kiński, Polski przemyst obronny a narodowy komponent taktycznej obrony przeciwrakietowej, "Nowa Technika Wojskowa" 2011, No. 5, pp. 24-25.

${ }_{18}$ ASD Facts \& Figures - 2010, op. cit., p. 4.

19 Ibidem, p. 12. 
defence industrial and technology base without identifying themselves with the arms sector. $^{20}$

In the post-cold war market environment greater integration of civil and defence sectors is a growing trend. It stems primarily form a fact that, due to profound changes in many state's defence postures and worsening budgetary outlook, it is ever more difficult for the companies to make desired profits (or even sustain themselves) from defence procurement alone. Additionally, the direction of technology transfer between the sectors has partially changed. Traditionally, military R\&D resulted in spin-offs to the civilian industry. Right now, it is ever more frequent for defence contractors to use the so called Commercial off-the-shelf technologies (COTS) ${ }^{21}$ In this way, enterprises can benefit from presence in both civilian and military market. Dual revenue streams contribute to company's financial stability while benefits can be drawn from the synergy of $R \& D$, as well as production, across the civil and military domain. Airbus offers a great example. The company has successfully used its proven airliners as a base for military applications. When it comes to civil-defence integration European industry fares quite good. Many top defence companies in Europe have a record of significant civilian sales, contrary to most of the biggest US defence contractors. ${ }^{22}$ For example around the middle of the past decade, US aerospace companies had a median share of the defence sales to the tune of $50 \%$, while their European counterparts' median was $38 \%{ }^{23}$

\section{INTERNAL WEAKNESSES}

The single most important weakness of the European defence industry is its fragmentation. In can be argued that there are simply too many small companies, which are unable to create the sort of "economies of scale" effects currently sought after in the global market. It is difficult to properly asses the exact number of defence companies, mainly because of difficulties in properly defining which entities are in the "defence business" and which are only supporting it. ${ }^{24}$ The ASD puts the number of leading players at around 20, followed by ca. 100 large and medium companies (mainly suppliers) and vast number of specialised Small and Medium Enterprises (SME) ${ }^{25}$ As has already been outlined in preceding paragraphs, after the year 1989 defence markets in the western world evolved in direction of much more competitive environment. In the USA the response from both industry and government was a drive towards concentration. In effect, during the 1990s American market witnessed creation of several big contractors

${ }^{20}$ Development of a European Defence Technological and Industrial Base, report by TNO for the European Commission, 2009, http://ec.europa.eu/enterprise/sectors/defence/files/edem_final_report en.pdf (14.06.2012), p. 3.

${ }^{2 \top}$ Ibidem, pp. 60-61.

22 Development of a European Defence Technological and Industrial Base, op. cit., p. 13.

23 Ibidem, p. 15.

24 Development of a European Defence Technological and Industrial Base, pp. 8-9.

25 ASD Facts \& Figures - 2010, op. cit., p. 11. 
which dominated domestic procurement and became global champions. ${ }^{26}$ At the same time in Europe, despite considerable movement towards increased mergers and acquisitions, the industrial landscape didn't change that much. In effect, European defence companies tend to be significantly smaller than their American competitors. When comparing top US and European aerospace companies one report stated that average American entity was about 22 times larger than its European counterpart. ${ }^{27}$ In the land sector the average American company was 1.5 times bigger than the European one, ${ }^{28}$ and in the naval sector this ratio climbs to $3.4 .^{29}$

Fragmentation weakens the European defence sector in several ways. As already mentioned, it denies the effects of scale and synergy (both in terms of orders and available resources). What is even more problematic, it creates large-scale redundancies and stirs intra-European competition. Currently there are simply too many manufacturers offering similar products. For example, EU-based producers offer 3 types of multirole combat aircraft and 4 models of Main Battle Tanks. There are also 16 producers of Armoured Fighting Vehicles, 3 of $155 \mathrm{~mm}$ howitzers ${ }^{30}$ and two industrial centres capable of producing nuclear-powered submarines. The shrinking European defence market is simply unable to sustain such a variety of platforms. In external markets European bidders must fiercely compete not only with formidable US, Russian (and many other) competitors, but also among themselves. Main obstacle to rationalization is political. Contrary to America, where one national market and regulatory framework exists, EU is practically divided into 27 separate defence markets and procurement processes. Often, governments strive to protect their national defence industries in the interest of sovereignty. They are also interested in provision of all defence industry's functions (as described earlier in this paper) on a national level.

\section{EXTERNAL THREATS}

At the moment, two significant threats can be identified in European defence industry's external environment. They concern both its domestic markets in Europe, as well as the global business environment in this sector. First, EU member states, which traditionally spent much less on defence than their American ally, are under intensive fiscal pressure to scale-down their government expenditure. Trend towards austerity, caused by the global financial crisis and especially the situation in the euro zone, has lead to

${ }^{26}$ H. L. E. Meijer, Post-Cold War Trends in the European Defence Industry: Implications for Transatlantic Industrial Relations, "Journal of Contemporary European Studies" 2010, Vol. 18, No. 1, p. 65; K. Hayward, The globalisation of the Defence business, in: Europe's Defence industry: a transatlantic future?, G. Adams, A. Ashbourne, L. Boureau, B. Clark, C. Crane, K. Hayward, T. Hitchens, R. Laird, D. Verret, S. von Henneberg, Centre for European Reform, 1999, pp. 10-12; The Defence Industry in the $21^{\text {st }}$ Century Thinking Global ... or thinking American?, PricewaterhouseCoopers 2005, http://www.pwc.pl/en/publikacje/defence_industry_ads.pdf, (11.06.2012), pp. 11-17.

27 Development of a European Defence Technological and Industrial Base, op. cit., p. 14.

28 Ibidem, p. 19.

29 Ibidem, p. 23.

${ }^{30}$ Ibidem, pp. 20-21. 
significant cuts in defence budgets across the continent. According to data compiled by the International Institute for Strategic Studies for the 2008-2010 period, real-terms reductions in defence spending occurred in 16 out of the 23 European NATO members. In over $40 \%$ of those states expenditure decline amounted to more than $10 \%$. In effect, total NATO Europe defence spending fell by $5.4 \%$ during the aforementioned period. ${ }^{31}$ In year 2011 Europe was overtaken by Asia and Australasia in terms of global defence expenditure's share by region (with former taking the $18.3 \%$ to the second's $18.5 \%$ ). ${ }^{32}$ Data compiled by the European Defence Agency show that in year 2010 total defence expenditure of the Agency's member states remained at the same level as in year 2009. However, as a percentage of overall government expenditure they declined to the tune of $3.3 \% .{ }^{33}$ What is even more important from the industry's perspective, funding for investment in 2010 (equipment procurement as well as R\&D) was $0.1 \%$ lower than in the previous year. ${ }^{34}$ It may not seem especially severe, but it must be remembered that those are aggregate data for 26 states which participate in the EDA's work.

Cuts in particular states had been quite deep. For example, three leading EU states in field of both defence expenditure and military capability: France, Germany and UK have planned (and partially executed) significant cuts to both spending and force structures. France intends to cut its planned defence expenditure in the 2011-2013 period by $€ 3.5 \mathrm{bn}$. Germany aims to cut $€ 8.3 \mathrm{bn}$ from its defence budget up to year 2015. At the same time, far-reaching reductions in the number of MBTs, artillery pieces and submarines are envisioned. The Strategic Defence and Security Review, published by the UK government in October 2010, aims to institute severe cuts in spending, manpower and operational capabilities (in terms of in service equipment). For example, British Army (the land forces) will shed ca. 20,000 personnel by the year 2020. Entire classes of weapon systems have been reduced, most visibly the aircraft carriers and combat naval aviation (specifically the Harrier aircraft). Naval air capability will be restored only in the second half of this decade when new carriers will enter service. ${ }^{35}$ Those developments have very serious implications for the European defence-industrial base. Since the end of the cold war the domestic European markets had been shrinking, impinging on defence companies' market position. After the last wave of cuts (which, considering the economic situation in Europe, must not necessarily be the last one) serious questions arise whether servicing the shrinking European armed forces' structures will be enough to ensure the further development of the defence-industrial base (or perhaps even to maintain its current position).

Considering the trends described above it seems that the future of Europe's defence sector will be ever more dependent on export sales to non-EU states. But those markets also became more demanding. Despite unfavourable global economic outlook dynamic

\footnotetext{
31 The Military Balance 2012, International Institute for Strategic Studies, London 2012, p. 74.

Ibidem, p. 31.

33 Europe and United States Defence Expenditure in 2010, European Defence Agency, 12.01.2012, http://www.eda.europa.eu/publications/12-01-12/EU-US_Defence_Data_2010 (17.06.2012), p. 4.

34 Ibidem, p. 7.

35 The Military Balance 2012, op. cit., pp. 76-87; Ł. Pacholski, Czy na pewno po kryzysiepaństwa NATO tnq budżety obronne, "Nowa Technika Wojskowa" 2010, No. 11, pp. 34-38; R. Czulda, Wielka Brytania cięcie potęgi, "Nowa Technika Wojskowa" 2012, No. 2, pp. 48-54.
} 
sources of demand for defence materiel remain (especially in Africa, Asia and the Middle East). ${ }^{36}$ However, global defence companies must operate in much more competitive field than two decades ago. Recently, many new players entered the market, often pursuing aggressive expansion strategies. There were 23 companies from outside North America and Western (NATO and EU) Europe in the "Top 100 efence companies" ranking of the "Defense News" magazine for year 2010. They represent such states as Russia, Japan, Israel, South Korea, India or Turkey. ${ }^{37}$ It points to a trend in which defence contractors from the so called "emerging economies" (like for example Brazil, South Korea or Turkey) are not only catering for the greater share of their own armed forces' needs, but are also looking for export opportunities. They have scored some successes. To name just a few: Brazilian Embraer has a strong position in the sector of training/light attack aircraft, as well as airframes for specialist applications, ${ }^{38}$ Turkish Ottokar successfully promotes its armoured vehicles around the world ${ }^{39}$ and South Koreans have won the competition for assistance in development of the new Turkish MBT (Altay). ${ }^{40}$

Many states, which were traditionally importers of defence equipment, develop their defence industries energetically. Moreover, they see expansion to foreign markets as an important part of this strategy. For example, the Turkish government envisions its defence industry to position itself among the ten biggest globally. In year 2016 it should reach turnover of $\$ 8 \mathrm{bn}$ domestically and additional $\$ 2 \mathrm{bn}$ in export sales. ${ }^{41}$ Saudi Arabia plans to invest more than $\$ 1 \mathrm{bn}$ in the next two years in defence manufacturing development. The desired end state is to produce $80 \%$ of the arms for the Kingdom's armed forces domestically. ${ }^{42}$ Report prepared by ECORYS for the European Commission highlights the development of defence industry in the so called BRICKs states (Brazil, Russia, India, China and South Korea). ${ }^{43}$ Although the authors believe that in the foreseeable future companies from those states will not pose significant competitive threat to European producers, they cannot be ignored. Russia has established a strong position in the global defence market in the last two decades. Chinese companies have a presence mainly in the less wealthy states, but recently a Chinese company expressed interest in offering its aircraft to the US Department of Defense. Naturally this offer hadn't

36 Background paper on SIPRI military expenditure data, 2011, Stockholm Peace Research Institute, 04.2012, http://www.sipri.org/research/armaments/milex (17.06.2012).

37 Defense News Top 100 for 2010, op. cit.

38 Study on the industrial implications in Europe of the blurring of dividing lines between security and defence, 15.06.2010, http://ec.europa.eu/enterprise/sectors/defence/documents/index_en.htm (22.06.2012), pp. 208-209, 213.

39 Otokar - Military Armoured Vehicles, "army-technology.com", http://www.army-technology.com/ contractors/vehicles/otokar/ (23.06.2012).

40 Otokar Altay MBT (Turkey), MBTs and medium tanks, "Jane's", http://articles.janes.com/articles/Janes-Armour-and-Artillery/Otokar-Altay-MBT-Turkey.html (23.06.2012).

${ }_{41}$ Turecki program 5-letni, "Raport Wojsko Technika Obronność" 2012, No. 4, p. 75.

42 W. Łuczak, K. Skrzypiński, International Armoured Vehicles 2012 Pancerz w czasach kryzysu, "Raport Wojsko Technika Obronność" 2012, No. 4, p. 28.

${ }^{43}$ FWC Sector Competitiveness Studies - Study on the Impact of Emerging Defence Markets and Competitors on the Competitiveness of the European Defence Sector, ECORYS, 12.02.2010, http://ec.europa.eu/enterprise/sectors/defence/files/study_defence_final_report_en.pdf(22.06.2012). 
been treated seriously, but the fact itself is ominous. ${ }^{44}$ Indian manufacturers, for the time being, have serious problems in meeting the needs of their own armed forces. South Korean companies are gaining expertise quickly. Korea Aerospace Industries (KAI) is engaged in intense marketing operation for its advanced T-50 Golden Eagle trainer aircraft. There is also a joint Indonesian-South Korean program for the development of next-generation combat aircraft. ${ }^{45}$ Considering all those developments European defence companies are facing a very demanding international market in which securing new contracts will undoubtedly prove ever more difficult.

\section{EXTERNAL OPPORTUNITIES}

Negative trends in external environment (both inside and outside the EU) can potentially be offset by some new opportunities. Despite cuts described above, EU and NATO member states are committed to the maintenance of core military capabilities and support for their defence industry. A growing understanding exists that significant reforms in the fields of defence-industrial policy and military capability development are needed to ensure this. From the very beginning, defence procurement was excluded from the internal market regime. Article 296 of the EC Treaty (now art. 346 TFEU) in its traditional interpretation, allowed member states to exempt purchases of significance to serious national security interests from open European competition. ${ }^{46}$ This prohibited the creation of single, integrated market for defence goods. The consolidation of this market had been a long-standing goal for those who believed it to be crucial for greater efficiency in defence procurement and rationalization of Europe's defence industry.

In the latter half of the last decade European Commission introduced a package of reforms aimed at removing the most important obstacles to defence market liberalisation. It comprises the following acts: Interpretative Communication on Article 296 (present Article 346) from year 2006, Defence Procurement Directive 2009/81/EC and Intra-EU Transfer Directive 2009/43 EC. These new regulations can lay the groundwork for the thorough transformation of the European defence sector. New interpretation of the Article 346 aims to make its application an exception, reserved for the protection of truly "significant" national security interests. If applied, it would severely limit member state's ability to use "national security" clause as an excuse for protectionism. The defence procurement directive provides common EU-wide legal framework for conducting defence acquisition programmes, open to Union-wide competition (naturally with several exceptions related to national security and multinational cooperation). The final directive is targeted at extensive arms-exports controls which had been

44 Chińska oferta dla Pentagonu, "Raport Wojsko Technika Obronność" 2011, No. 2.

45 KAI bids to spread wings with Golden Eagle, "Flight Global", 14.10.2011, http://www.flightglobal.com/news/articles/kai-bids-to-spread-wings-with-golden-eagle-362567/ (23.06.2012).

46 E. Aalto, Interpretations of Article 296, in: Towards a European Defence Market, (ed.) D. Keohane, "Chaillot Paper" 2008, No. 113, http://www.iss.europa.eu/uploads/media/cp113.pdf (22.06.2012), pp. 13-49. 
a significant obstacle to efficient pursuit of cross-border trade in defence goods. Considering the high level of trust and defence cooperation among the member states, it has been concluded that the issuance of export licences can be simplified for the intra-EU transfers. It should make arms trade easier and assuage fears about security of supply. This new EU legal framework provides a very serious opportunity for creation of a single, truly "European" defence market. It would provide stimulus for consolidation of European defence companies. It could also provide those new large entities with market potentially big enough to sustain them, creating situation somewhat similar to the one prevalent in the USA. ${ }^{47}$

Another area of increased European cooperation in the defence sector is the growing trend towards joint development and maintenance of military capabilities. Confronted with shrinking national financial means, European states recognize the need to combine them in order to maintain required potential. It corresponds strongly with the concept of "smart defence", advocated by NATO's Secretary General Anders Fogh Rassmussen at the Organization's summit in Chicago in May 2012. ${ }^{48}$ Bastian Giegerich names five basic forms of new defence cooperation: capability sharing (joint use of national resources), capability pooling (delegation of national capabilities for use in multinational structure), role and task sharing (state specializes in some determined military capabilities and depends on others to provide the rest), joint acquisition (states collaborate to acquire and operate capabilities inside international framework) and co-development (joint development and production of military equipment for several states). ${ }^{49}$ As defence budgets across Europe shrink even further, such measures will offer some hope for compensating the corresponding loss of capabilities. From the industry's point of view, such schemes may provide a way to sustain demand and create sustainable framework for development of next-generation products.

Another opportunity comes from the foreign markets. As already mentioned, there are regions (such as Africa, Asia and the Middle East) where demand for the defence materiel is rising. Despite fierce competition, European companies still have significant strengths form which to derive competitive advantages (both issues have been described earlier in this paper). The aforementioned report by ECORSYS for the EC highlights that, despite considerable development, defence industries of most BRICKs states have quite limited market penetration. Their ability to reliably develop and deliver sophisticated systems is also subject of doubt. ${ }^{50}$ In contrast, EU-based firms have

47 Towards a European Defence Market, op. cit.; J. Hofbauer, R. Levy, G. Sanders, European Defense Trends Budgets, Regulatory Frameworks and the industrial base, A report of the CSIS Defense-Industrial Initiatives Group, 11. 2010, http://csis.org/files/publication/100518_European_Defense_Trends.pdf, 22.06.2012, pp. 22-30; C. M. O'Donnell, The EU finally opens up the European defence market, "Centre for European Reform Policy Brief", 06.2009, http://www.cer.org.uk/ sites/default/files/publications/attachments/pdf/2011/policybrief_defencemarket_june09-745.pdf (22.06.2012).

48 B. Giegerich, NATO's Smart Defence: Who's Buying?, "Survival Global Politics and Strategy" 2012, Vol. 54, No. 3, pp. 69-77.

${ }^{49}$ B. Giegerich, Budget Crunch: Implications for European Defence, "Survival Global Politics and Strategy" 2010, Vol. 52, No. 4, pp. 90-94.

${ }^{50}$ FWC Sector Competitiveness Studies, op. cit., pp. 233-241. 
an impressive record of successful programs and a rich offer of proven products. Thus, they are well positioned to benefit from some potentially lucrative markets.

Several examples are in order. In January 2012 French company Dassault Aviation has won the prestigious MMRCA (Medium Multirole Combat Aircraft) competition in India with its Rafale fighter. The pending contract to supply 126 aircraft is thought to be worth between $\$ 10 \mathrm{bn}$ and $\$ 15 \mathrm{bn} .{ }^{51}$ India can be viewed as a very promising defence market because of its armed forces' size, their requirements for sophisticated weapon systems and persistent inability of its sizeable defence industry to meet military's needs. In recent years Russia has opened its defence procurement for foreign biders to the level unprecedented in its post-soviet history. State, which itself is a major arms exporter, seems determined to meet its armed forces' needs with sophisticated foreign equipment. This trend stems from drive for rapid modernization of military capabilities (partially effect of experiences of the Five Day War of 2008) and perceived inability of the domestic manufacturers to provide satisfying products. European companies have already benefited from this development. The order of French Mistral class amphibious vessels is a flagship project in this regard. Italian Iveco is also poised to cooperate with Russian companies in production of armoured vehicles for the Russian Ministry of Defence. ${ }^{52}$ Even the US defence market, dominated as it is by domestic giants becomes more open for European firms. Although the Airbus's victory in the competition to equip United States Air Force with new tanker aircraft was short-lived and order eventually went to Boeing, European contractors can play the role of key partners in some promising programmes (like for example Ground Combat Vehicle or Marine Personnel Carrier). ${ }^{53}$

\section{WHAT FUTURE FOR THE EUROPEAN DEFENCE INDUSTRY?}

Trends and developments described in this paper seem to substantiate the notion that current financial and economic crisis can mark the turning point in the evolution of European defence sector. The evolving domestic and international markets, as well as ever changing international strategic and military context require significant adaptation on the industry's side. That is why this article will end with short analysis of possible future directions of EU-based defence sector's evolution. Naturally, those trends do not constitute closed, autonomous scenarios and can conceivably overlap and criss-cross themselves. The purpose here is more to sketch out different processes which can determine the future outlook of Europe's defence-industrial base.

First of all, it is useful to consider the implications of the "status quo" scenario. With lack of significant reforms and continuity of present trends, it is conceivable that

\footnotetext{
51 Ł. Pacholski, MMRCA dla Rafale, "Nowa Technika Wojskowa" 2012, No. 3.

52 W. Łuczak, Rosja szeroko otwarta na Zachód, "Raport Wojsko Technika Obronność" 2012, No. 2, pp. $48-52$.

53 KC-46A USAF Aerial Tanker: From KC-XRFPs to Decision and Execution, "Defense Insustry Daily", 10.05.2012, http:/www.defenseindustrydaily.com/the-usafs-kcx-aerial-tanker-rfp-03009/ (22.06.2012); and W. Łuczak, K. Skrzypiński, op. cit.
} 
European defence-industrial base can experience stagnation and gradual decline. The current state of the industry can prove to be unsustainable. Basically, a plethora of relatively small companies dispersed around 27 national markets (practically all of them shrinking) will encounter growing difficulties to survive commercially the current adverse fiscal climate. At the same time, while the organizational structure of Europe's defence sector is highly fragmented, its turnover/profits structure is quite concentrated. As noted by the ASD, in 2010 six biggest companies (EADS, BAE Systems, Finmeccanica, Thales, Rolls-Royce and Safran) were responsible for 3/4 of the entire aerospace and defence sector's turnover. ${ }^{54}$ Thus, it can be argued that in case the "status $q u o$ " scenario is realized, this small "elite" of highly competitive companies with strong market position will survive and prosper. Those companies will be able not only to secure what European procurement contracts will remain in the offing, but also successfully compete in the global market. At the same time many smaller enterprises with less competitive advantages to draw on can face decline and even go out of the business entirely. It is worth noting that this competitive structure of the European defence industry has quite clear geographical dimension. Majority of best performing firms comes from six LoI signatory states. ${ }^{55}$ Realization of such scenario can lead to (to borrow a popular phrase from the European integration lexicon) "Europe of different speeds" in defence-industrial matters, with traditional industrial and export "champions" maintaining their positions and gaps opening in other functional and geographical areas of the industrial landscape.

Several scenarios for perseverance and development of European defence industry are possible. As already mentioned, there is a strong constituency for "more Europe" in this realm. EU member states can decide to purse something that can be called "triple consolidation" - of market (creating common market for defence goods), demand (joint acquisition and co-development) and supply (consolidation of the defence-industrial base in direction of several big entities). Naturally, consolidation must not proceed simultaneously and with same scope in all three areas. However, they are mutually supportive and greatest effects in terms of capability maintenance and market expansion can potentially be achieved with the full realization of this programme. Current trends in the global defence sector seem to favour large companies, combining products and expertise from different segments and thus able to offer complete, integrated combat systems. Such firms are also able to muster resources necessary to pursue sophisticated R\&D efforts or manage complex defence programs and partnerships. Such large enterprises require correspondingly large markets in order to sustain their business operations. Thus the need to extend the European common market rules to the defence sector. However, considering the current budgetary pressures, it is hardly conceivable that common market with demand fragmented into 27 national armament programs could generate desired effects. It seems that new, creative tools from the field of "smart

54 ASD Facts \& Figures - 2010, op. cit., p. 11.

55 "The Letter of Intent (LoI) Framework Agreement Treaty was established to create the necessary measures to facilitate the restructuring of the European defence industry and was signed on 27 July 2000 by the Defence Ministers of France, Germany, Italy, Spain, Sweden and the UK". ASD Facts \& Figures - 2010, op. cit., p. 9. 
defence" (like joint acquisition and co-development) will become ever more widespread across Europe.

If the triple consolidation is realized, than situation in Europe will resemble that in the USA (i.e. large domestic market, sustaining big and competitive companies). However the American example also points to same negative effects of such developments. It is widely noted that consolidation of defence industry in the USA has created a virtual oligopoly, with few large contractors securing the lion's share of defence procurement. Lack of competition is one of factors causing inefficiencies, cost overruns and delays in many American defence programmes. Creating "pan-European champions" can lead to expectations that they will receive all major orders practically "automatically" without an open bidding process. Political pressures and lobbying could conceivably lead to closure of European defence market for foreign firms and creation of protectionist "fortress Europe". ${ }^{56}$ That would deprive governments of benefits (like effectiveness and cost-efficiency) brought by competition and also provoke other states to reciprocally close their markets for European products.

Market consolidation could arguably proceed even further with the creation of trans-Atlantic defence market. United States and Western Europe have a long and generally successful record of defence policy coordination, military cooperation and joint defence-industrial undertakings thanks to the NATO framework. However, the benefits of industrial cooperation to date have been rather one-sided. More often than not, US companies benefited the most by supplying European nations with their products (with more or less advanced participation from European industrial partners). At the same time US defence market has been largely closed for EU-based firms. This situation has generated much mistrust between the two sides. The case of the American $\mathrm{KC}-\mathrm{X}$ programme is emblematic in this regard. Although EADS won the competition to supply new tanker aircraft to the USAF (going to significant lengths in order to accommodate US demands, like teaming with Northrop Grumman and planning to manufacture aircraft at a US-based plant), political pressures lead to repetition of the tender and award of final contract to Boeing (amid accusations of unequal treatment). ${ }^{57}$

Those negative experiences notwithstanding, it is clearly visible that US Department of Defense (DoD) is becoming more open to working with European contractors and companies from both states learn to cooperate better. EU-based firms have worked hard to establish footholds in the US market and in many cases they have succeeded. Several business models have been employed to achieve this goal. BAE Systems simply bought several American defence companies and created a US subsidiary, fully compliant with stringent security requirements of the federal government. At the other hand, $E A D S$ build its own operations in North America, opening manufacturing plants for the needs of DoD awarded contracts. In third example, Thales established a joint-venture with US giant Raytheon to successfully pursue undertakings in North America. Further integration of US and European defence markets could bring additional benefits. More industrial cooperation would make the allies' militaries even more interoperable. De-

56 B. Clark, More harm than good? The dangers of defence industry consolidation, in: Europe's Defence industry: a transatlantic future?, op. cit., pp. 16-21.

57 KC-46A USAF Aerial Tanker: From KC-X RFPs to Decision and Execution, op. cit. 
fence companies from both sides of the Atlantic could find new market opportunities for sales and mergers (possibly leading to even greater consolidation). Finally, US government could benefit from European firms' expertise and increased competition in its defence procurement process (ideally with better results with lesser costs). However, significant obstacles for such a scenario exist. They primarily concern the political pressures on both sides to preserve national industries. ${ }^{58}$

If efforts at the expansion of the "domestic" market fail, European defence sector may be forced to fall into greater export dependency. As already mentioned, there are ample opportunities on the global market to secure profitable contracts for supply of weapons and military equipment. At least some EU-based companies have significant advantages which could put them in good position to secure a sizeable part of such deals. With shrinking demand on domestic markets the pressure for greater export orientation will grow. This could lead to a situation in which European companies derive most of their turnover and profits from extra-European markets. While this could sustain them for some time, many risks accompany such a scenario. Similar developments have taken place in Russia after the break-up of the Soviet Union. With meagre orders from national armed forces Russian companies aggressively pursued foreign sales. It has lead to a partial overturn of a traditional pattern in which weapon systems are developed for the domestic consumer and then exported. In Russia, in the last two decades, the opposite was often true. New products had been developed for export customers with little interest from domestic buyers. Such a model is hardly attractive for the host government, which draws little military benefits from such a state of affairs.

It is important to remember that many potential customers are interested in development of their own defence industry. Thus industrial cooperation can be an important prerequisite for securing profitable deals. That is why European companies could nurture their own future competitors. Growing trend towards industrial cooperation can point to another avenue for European defence industry development. Defence companies could perhaps "globalise their operations", much like many non-defence companies did. A situation can be envisaged where large part of products' assembly (mostly, but not exclusively for export sales) is conducted in offshore locations by industrial partners form customer states. Thus, the relatively simple and costly part of the operation would have been outsourced, while the core of the business (mainly R\&D, marketing for domestic needs) would remain in Europe. Prime contractors could also provide profitable services, like training or technical maintenance. Perhaps, from a strictly business point of view, such a model could offer benefits in terms of market access and efficiency gains. However, it is far from guaranteed that it could be employed to the defence sector. Consent of European governments could be hard to obtain. And the question remains for how long customers/industrial partners from "emerging markets" would be content with the role of cheap producers.

Finally, diversification of activity to new areas (such as civil production or security equipment) could offer the defence companies opportunity to secure profits in

58 C. M. O’Donnell, A transatlantic defence market, forever elusive?, "Centre for European Reform Policy Brief”, 07.2010, http://www.cer.org.uk/sites/default/files/publications/attachments/ pdf/2011/pb_transatlantic_defence_july10-704.pdf (22.06.2012). 
times of restrained defence budgets. As mentioned earlier in this paper, many European companies successfully draw benefits from dual-business models (civilian and military). In new security environment after the end of the Cold War, and especially after the $9 / 11$ attacks, new emphasis has been put on internal/homeland security missions. It was expected, that defence sector could find new business opportunities in the form of supplying their products to law enforcement/crisis management services. ${ }^{59}$ However, report prepared by a consortium led by the Istituto Affari Internazionali for the European Commission concludes that significant obstacles remain for defence companies to profit from "the blurring of dividing lines between security and defence". This situation is a product of the security market's fragmentation, dynamic nature and difficulties in transferring defence expertise/solutions into this field. However, under right circumstances, potential for profitable forays into this market exists. ${ }^{60}$

This paper aimed to show that, due to important functions performed by the defence industry (military, political, economic and even welfare), the direction of its future development will be of serious significance for the EU member states and for the EU as a whole. If the Union aims to be an important player in international political and strategic relations it should posses corresponding means (adequate defence-industrial base among them). Analysis provided in this paper shows that the EU-based defence companies posses significant competitive strengths. At the same time, the external environment is a source of significant threats in form of shrinking domestic markets and highly competitive global business environment. However, potential opportunities can (at least partially) balance those threats. As described above, the further development of Europe's defence sector can progress among many different paths. It is difficult to assess the probability of their realization. It seems however, that in order to preserve and expand its position, it will have to be open to creative changes, in form of new business models, product categories or new ides in the realm of defence policy.

\begin{abstract}
Current economic crisis in the EU can prove to be a turning point for the European defence-industrial base. The purpose of this article is to analyse the current state of the EU-based defence sector and possible trajectories of its future evolution. In order to achieve this aim, an overview of defence industry's functions has been provided, followed by SWOT analysis of internal and external factors influencing the current and future position of the European defence-industrial base. Presentation of the sector's strengths and weaknesses, as well as threat and opportunities coming from the external environment provides basis for assessment of possible future directions of industry's evolution.

59 Study on the industrial implications in Europe of the blurring of dividing lines between security and defence, op. cit., pp. 29-63.

${ }^{60}$ Ibidem.
\end{abstract}




\section{PRZEMYSŁ OBRONNY W UNII EUROPEJSKIEJ - WYZWANIA I SZANSE W CZASACH KRYZYSU EKONOMICZNEGO}

\section{STRESZCZENIE}

Obecny kryzys gospodarczy w Unii Europejskiej może okazać się punktem zwrotnym dla europejskiej bazy przemysłowo-obronnej. Celem tego artykułu jest przedstawienie analizy obecnego stanu sektora obronnego UE oraz możliwych kierunków jego dalszego rozwoju. Dla osiaggnięcia tego celu, przedstawiono krótka charakterystykę funkcji przemysłu obronnego a następnie analizę SWOT wewnętrznych i zewnętrznych czynników wpływających na obecną i przyszła pozycję europejskiej bazy przemysłowo-obronnej. Prezentacja silnych i słabych stron tego sektora, jak również szans i zagrożeń występujących w jego otoczeniu zewnętrznym stworzyła podstawę dla nakreślenia możliwych dalszych kierunków ewolucji tej gałęzi przemysłu. 
